\title{
A New Class of Mutants of the cysB Regulatory Gene for Cysteine Biosynthesis in Salmonella typhimurium
}

\author{
By A. WIATER, M. FILUTOWICZ AND D. HULANICKA* \\ Institute of Biochemistry and Biophysics, Polish Academy of Sciences, ul. Rakowiecka 36, \\ 02-532 Warsaw, Poland
}

(Received 23 July 1981; revised 2 October 1981)

\begin{abstract}
A new class of regulatory mutants in the $c y s B$ locus has been isolated by plating $c y s M$ strains, under anaerobic conditions, on medium containing 1,2,4-triazole. The isolated cys $B$ mutants are cysteine prototrophs and triazole-resistant, although the levels of cysteine and $O$-acetyl-Lserine sulphydrylase are not changed. In contrast to the constitutive cys $B$ mutants identified previously, the expression of the cysteine biosynthetic enzymes in the newly isolated mutants is regulated by the same factors as in wild-type strains. In the double mutant $c y s E$ cys $B 2971$, the cysteine biosynthetic enzymes are absent with the exception of $O$-acetyl-L-serine sulphydrylase.
\end{abstract}

\section{INTRODUCTION}

The cysB region in Salmonella typhimurium and Escherichia coli is involved in the positive regulation of the cysteine regulon (Spencer et al., 1967; Jones-Mortimer, 1968; Kredich, 1971). The detection of temperature-sensitive and amber mutations in $c y s B$ indicates that the gene product is a protein (Tully \& Yudkin, 1975). The fine-structure genetic mapping of the cys $B$ region suggests that it codes for a single polypeptide chain (Cheney \& Kredich, 1975). Most known $c y s B$ mutations result in cysteine auxotrophy and these $c y s B$ strains cannot be derepressed for cysteine biosynthetic enzymes by any known nutritional means. A few prototrophic cys $B$ constitutive mutants were found in the course of biochemical analysis of cysteine-requiring strains (Kredich, 1971). Recently, Sledziewska \& Hulanicka (1978) described a method for selection of cysteine constitutive strains by plating cys $M$ strains on medium containing 1,2,4-triazole. The $c y s B^{\mathrm{c}}$ strains have high levels of cysteine biosynthetic enzymes even in the absence of $O$-acetyl-L-serine and these enzymes are not repressed by the addition of L-cysteine. The cys $B^{\mathrm{c}}$ strains are triazole- and selenate-resistant. They excrete sulphide which feeds cysteine auxotrophs and enables the growth of wild-type strains on triazole plates. An interesting, partially constitutive mutant, cys $B 484$, has been described by Kredich (1971); this is a cysteine auxotroph with respect to the pathway of sulphate reduction but constitutive for the expression of $O$-acetylserine sulphydrylase. Sulphydrylation of $O$-acetyl-L-serine in $S$. typhimurium is catalysed by two sulphydrylases, A and B, coded by the genes cysK and cysM, respectively (Hulanicka et al., 1979). Therefore, although cysteine auxotrophy occurs in strains lacking both enzymes, the cys $K$ or $c y s M$ mutation alone does not lead to a requirement for cysteine. However, it has been observed that although cys $M$ strains grow at a normal rate on minimal medium, they become cysteine bradytrophs under anaerobic conditions (Filutowicz \& Hulanicka, 1978). We were therefore interested to see what kind of mutants might be obtained by plating $\operatorname{cys} M$ strains under anaerobic conditions on triazole plates. The present communication describes a regulatory $c y s B$ mutant of $S$. typhimurium with novel properties. 
Table 1. Designation and derivation of bacterial strains

Strain Genotype Source or derivation*

Salmonella typhimurium LT2

\begin{tabular}{|c|c|c|}
\hline TK 1000 & Wild-type & N. D. Zinder \\
\hline DW24 & cysE396 & N. M. Kredich \\
\hline DW 25 & cys $B^{\mathrm{c}} 1352$ & N. M. Kredich \\
\hline DW221 & $\begin{array}{l}\text { ara-9 his-340 thy trpA } 160 \text { pyrF } 146 \\
\text { trpC109 }\end{array}$ & N. M. Kredich \\
\hline TK 1470 & $\operatorname{cys} A 20$ & K. E. Sanderson \\
\hline TK 1530 & $\operatorname{trpA} 52$ cys $B 12$ pyrF 146 & K. E. Sanderson \\
\hline TK 1513 & pyrE 125 & K. E. Sanderson \\
\hline TK 1001 & pyrE125 trp-1 & NG-induced mutation in TK \\
\hline SB 3751 & $\Delta(c y s K-p t s H I 182) \operatorname{trpB} 223$ & J. C. Cordaro \\
\hline TK2058 & $\begin{array}{l}\Delta(\text { cysK-ptsHI182) cys M2328 } \\
\text { trpB } 223\end{array}$ & $\begin{array}{l}\text { Spontaneous mutation to aza } \\
\text { SB3751 }\end{array}$ \\
\hline TK2072 & cys $M 2328 \operatorname{trp} B 223$ & Transductant from TK 1000 \\
\hline TK2078 & cysM2328 & Transductant from TK 2072 \\
\hline TK2087 & cysM2328 cysB2971 & $\begin{array}{l}\text { Spontaneous mutation under } \\
\text { in TK } 2078\end{array}$ \\
\hline TK2090 & cysM2328 cysB2972 & $\begin{array}{l}\text { DES-induced mutation unde } \\
\text { conditions in TK2078 }\end{array}$ \\
\hline TK2085 & $\operatorname{trpB223}$ cysM2328 cysB2973 & $\begin{array}{l}\text { DES-induced mutation unde } \\
\text { conditions in TK } 2072\end{array}$ \\
\hline TK2098 & pyrF146 cysB2971 & Transductant from TK 2087 \\
\hline TK2135 & pyrE125 cysB2971 & Transductant from TK 2087 \\
\hline TK2140 & cys $B 2971$ cysE396 & Transductant from DW24 ly \\
\hline TK2176 & ara-9 hisC340 thy cys $B 2971$ & Transductant from TK 2087 \\
\hline TK 2177 & ara -9 his $C 340$ thy cys $B 2972$ & Transductant from TK 2090 \\
\hline TK2029 & pyrF146 cysB2971/pyrF ${ }^{+}$cysB $B^{+}$ & F-ductant TK2098 × CGSC \\
\hline \multicolumn{3}{|c|}{ Escherichia coli } \\
\hline \multirow[t]{2}{*}{ CGSC 4256} & $\begin{array}{l}\text { thi-1 pyrD34 his-68 trp-45 recAl } \\
\text { mtl-2 xyl-7 malA1 galK35 strA118 } \\
\lambda^{R} \lambda-/ \text { KLF } 123 \text { pyrF }{ }^{+} \text {cys }^{+} \text {trp }^{+}\end{array}$ & E. coli Genetic Stock Center \\
\hline & yl- $N^{\prime}$ & ne \\
\hline
\end{tabular}

METHODS

Bacterial strains and phages. Bacterial strains and their sources are listed in Table 1. The phage P22 mutant L4 was used for transduction (Smith \& Levine, 1967). Culture media and culture conditions were as described previously (Hulanicka \& Kłopotowski, 1972). The sulphate-free medium was supplemented with $0 \cdot 1 \mathrm{~mm}-\mathrm{Na}_{2} \mathrm{SO}_{4}$, $0.5 \mathrm{~mm}$-L-cystine or $0.5 \mathrm{mM}$-L-djenkolic acid.

Enzyme assays. NADPH-sulphite reductase (EC 1.8.1.2) activity was assayed by the method of Vito \& Dreyfuss (1964). O-Acetyl-L-serine sulphydrylase (EC 4.2.99.8) activity was determined according to Kredich (1971); one unit (U) of $O$-acetylserine sulphydrylase is defined as the amount of enzyme catalysing the formation of $1 \mu \mathrm{mol}$ cysteine $\mathrm{min}^{-1}$. Antibodies against $O$-acetylserine sulphydrylase-A were prepared and immunological determination of this enzyme was performed as described by Hulanicka et al. (1974).

Isolation of cys $B$ mutants. The new mutants were isolated by spreading $0.5 \mathrm{ml}$ of an overnight broth culture on $10 \mathrm{~mm}$-1,2,4-triazole minimal agar plates. The Petri dishes were placed in a vacuum chamber which was evacuated and refilled with nitrogen, thus providing almost completely anaerobic conditions. After incubation for a few days at $37^{\circ} \mathrm{C}$ colonies of mutants appeared; these were purified and their ability to grow on 10 mM-triazole was checked by replica plating.

Protein was determined by the biuret method (Gornall et al., 1949).

Chemicals. $O$-Acetyl-L-serine was prepared by the method of Sakami \& Toennies (1942). Other chemicals used were commercial products of reagent grade.

\section{RESULTS \\ Isolation of mutants}

The cys $M$ mutants were plated on $10 \mathrm{~mm}$-1,2,4-triazole solid agar media under anaerobic conditions. Since the cys $M$ mutants have a long generation time under these conditions, 
Table 2. Mapping of newly isolated triazole-resistant mutants

The recipient in the first and second crosses was TK 1001 ( pyrE125 trp-l); the recipient in the third cross was DW221 (trpA160 pyrF146 trpC109).

\begin{tabular}{|c|c|c|c|c|c|}
\hline \multirow{2}{*}{$\begin{array}{l}\text { Donor } \\
\text { strain }\end{array}$} & \multirow[b]{2}{*}{ Relevant genotype } & \multirow[b]{2}{*}{ Selection } & \multicolumn{2}{|c|}{$\underbrace{\text { No. of }}_{\text {recombinants }}$} & \multirow{2}{*}{$\begin{array}{c}\text { Cotransduction } \\
\text { (\%) }\end{array}$} \\
\hline & & & Total & $\mathrm{Trz}^{-}$ & \\
\hline TK2087 & cysM2328 cysB2971 & $\operatorname{Trp}^{+}$ & 104 & 32 & 30 \\
\hline $\begin{array}{l}\text { TK2090 } \\
\text { TK2087 }\end{array}$ & cysM2328 cysB 2972 & $\operatorname{Trp}^{+}$ & 104 & 27 & 26 \\
\hline TK2087 & cys M2328 cysB2971 & $\operatorname{Trp}^{+} \mathrm{PyrF}^{+}$ & 54 & 54 & 100 \\
\hline
\end{tabular}

Table 3. Activity of $O$-acetylserine sulphydrylase and sulphite reductase in newly isolated cys $B$ mutants and control strains grown on different sulphur sources

\begin{tabular}{|c|c|c|c|c|c|c|c|c|}
\hline \multirow[b]{2}{*}{ Strain } & \multirow{2}{*}{$\begin{array}{l}\text { Relevant } \\
\text { genotype }\end{array}$} & \multirow{2}{*}{$\begin{array}{l}\text { Sulphur } \\
\text { source. }\end{array}$} & \multicolumn{3}{|c|}{$\begin{array}{c}O \text {-Acetylserine sulphydrylase } \\
{\left[\mathrm{U}(\mathrm{mg} \text { protein })^{-1}\right]}\end{array}$} & \multicolumn{3}{|c|}{ 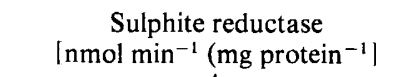 } \\
\hline & & & L-Djenkolate & Sulphate & L-Cystine & L-Djenkolate & Sulphate & L-Cystine \\
\hline TK 1001 & $\operatorname{cys} B^{+}$ & & 14 & 5 & 0.7 & 90 & 90 & 5 \\
\hline TK 2078 & cys $M 2328$ & & 16 & 0.9 & 0.2 & 80 & 10 & 6 \\
\hline TK2176 & 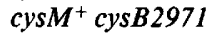 & & 16 & 8 & 1.4 & 108 & 72 & 12 \\
\hline TK2177 & cys $M^{+}$cysB2972 & & 20 & 5 & 0.9 & 136 & 58 & 6 \\
\hline DW25 & $\operatorname{cys}^{c} 1352$ & & 14 & 11 & $9 \cdot 4$ & 141 & 122 & 103 \\
\hline
\end{tabular}

triazole-resistant colonies appeared after a few days. These colonies were purified and their phenotypes were checked by replica plating.

\section{Genetic mapping of $\mathrm{Trz}^{-}$mutants}

Mapping of the isolated mutants was performed by P22-mediated transduction. So far, the known triazole-resistant mutants have been linked by P22-mediated transduction to three chromosomal markers: the cysK mutants with the pts operon (Hulanicka et al., 1974); the cys $B^{\mathfrak{c}}$ constitutive mutants with the $\operatorname{trp}$ operon and $p y r F$ gene (Sledziewska \& Hulanicka, 1978); and the cysE promoter-up mutant with pyrE (Hulanicka \& Kredich, 1976).

Phage lysates prepared on the isolated mutants were used as donors in crosses where the recipients carried the above markers, and the transductants were scored for their resistance phenotype. Linkage of the triazole resistance phenotype was found only with $\operatorname{trp}$ and $p y r F$ genes, and the triazole resistance mutation was $26-30 \%$ cotransducible with the trp gene (Taible 2). These results indicate that the mutations rendering colonies resistant to triazole are located in the cys $B$ region, since a similar linkage has been found for the cys $B$ locus (Cheney \& Kredich, 1975). In some crosses $\operatorname{trp}$ and $p y r F$ markers were transduced to prototrophy; this required transfer of the whole $c y s B$ gene and so the linkage cannot be calculated.

\section{Biochemical analysis}

To avoid any possible confusion due to the presence of secondary mutations, as well as the effect of the cys $M$ mutation, the biochemical assays were also performed on non-lysogenic transductants such as $\mathrm{PyrF}^{+} \operatorname{Trp}^{+} \operatorname{Trz}^{-}$.

The activities of $O$-acetylserine sulphydrylase and sulphite reductase in cells grown on different sulphur sources were assayed. All the enzymes of the reductive pathway are known to respond in parallel to each sulphur source (Kredich, 1971). Thus, sulphite reductase can be considered as representative of the entire reductive pathway. As shown in Table 3 , activities of both enzymes (sulphite reductase and $O$-acetylserine sulphydrylase) in the newly isolated 
Table 4. Repression index of $O$-acetylserine sulphydrylase and sulphite reductase in the wild-type, cysB $B^{c} 1352$ and transductants of the newly isolated cys $B$ mutants

The repression index is defined as the ratio of the enzyme activity of bacteria grown on L-djenkolic acid to the enzyme activity of bacteria grown on L-cystine.

\begin{tabular}{llcc} 
Strain & \multicolumn{1}{c}{$\begin{array}{c}\text { Relevant } \\
\text { genotype }\end{array}$} & $\begin{array}{c}\text { O-Acetylserine } \\
\text { sulphydrylase }\end{array}$ & $\begin{array}{c}\text { Sulphite } \\
\text { reductase }\end{array}$ \\
TK 1001 & cys $B^{+}$ & 20 & 18 \\
TK2078 & $c y s M^{2} 328$ & 80 & 13 \\
TK2176 & $c y s M^{+}$cys B2971 & 11 & 9 \\
TK2177 & $c y s M^{+}$cysB2972 & 22 & 23 \\
DW25 & $c y s B^{\complement} 1352$ & 1.5 & 1.4
\end{tabular}

Table 5. Activity of O-acetylserine sulphydrylase and sulphite reductase in cysE396, cysB2971 and cysB2971 cysE396 mutants

\begin{tabular}{|c|c|c|c|c|c|c|}
\hline \multirow[b]{2}{*}{ Strain } & \multirow[b]{2}{*}{$\begin{array}{l}\text { Relevant } \\
\text { genotype }\end{array}$} & \multirow[b]{2}{*}{$\begin{array}{l}\text { Sulphur } \\
\text { source. }\end{array}$} & \multicolumn{2}{|c|}{$\begin{array}{l}O \text {-Acetylserine } \\
\text { sulphydrylase }\end{array}$} & \multicolumn{2}{|c|}{ Sulphite reductase } \\
\hline & & & L-Djenkolate & L-Cystine & L-Djenkolate & L-Cystine \\
\hline DW24 & cysE396 & & 1.9 & 0.1 & 2 & 2 \\
\hline TK2135 & cysB2971 & & 14.0 & $1 \cdot 5$ & 110 & 12 \\
\hline TK 2140 & cysB2971 cysE & & $7 \cdot 0$ & 0.8 & 12 & 17 \\
\hline
\end{tabular}

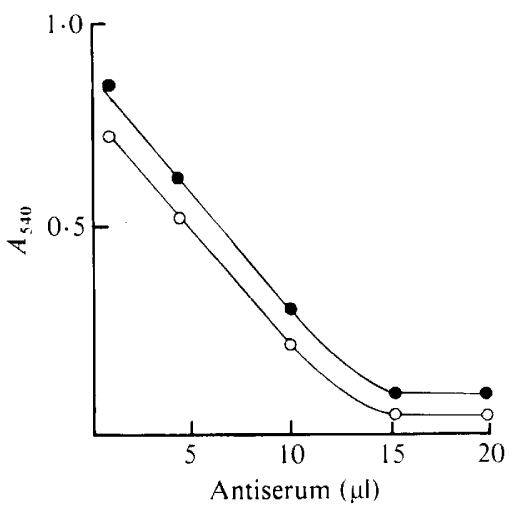

Fig. 1. Titration of $O$-acetylserine sulphydrylase-A of the $c y s B 2971$ strain (O) and the double mutant cysE396 cys $B 2971$ (O) with antiserum to $O$-acetylserine sulphydrylase-A.

mutants were similar to those in the wild-type strain (TK 1001). Growth on L-djenkolic acid caused derepression, whereas the presence of L-cystine repressed the enzyme activities. The normal regulation of cysteine biosynthetic enzymes in the $\mathrm{Trz}^{-}$mutants was clearly shown by comparison of the repression indexes of our mutants with that of the wild-type (Table 4). For both sulphite reductase and $O$-acetylserine sulphydrylase the repression indexes of our mutants were similar to that for the wild-type and varied from 9 to 23 , whereas that for the cys $B^{c}$ constitutive mutant was 1.4 (Śledziewska \& Hulanicka, 1978).

The $c y s B^{\mathfrak{c}}$ constitutive mutants are characterized by a derepressed, unregulated level of cysteine biosynthetic enzymes and the expression of the cysteine structural genes even in the absence of the internal inducer, $O$-acetylserine (Kredich, 1971). The introduction into the 
$c y s B^{\mathfrak{c}}$ mutant of a mutation in the $c y s E$ gene results in a requirement for cysteine. However, the cysteine biosynthetic enzymes in this double mutant, $c y s E$ cys $B^{\mathrm{c}}$, show the same activities as the parental strain, the cys $B^{\mathrm{c}}$ mutant (Kredich, 1971).

It was of interest to determine whether the presence of the inducer is dispensable for the expression of cysteine biosynthetic enzymes in the newly isolated mutants. The cysE396 cysB2971 strain, which is a non-reverting cysteine auxotroph totally lacking serine transacetylase (EC 2.3.1.30) activity, was grown on media with different sulphur sources and the activities of $O$-acetylserine sulphydrylase and sulphite reductase in crude extracts were assayed. The results (Table 5) show that the cysE396 mutation slightly affects the activity of $O$-acetylserine sulphydrylase, whereas it leads to a lack of sulphite reductase activity.

In the wild-type, total sulphydrylase activity consists of two sulphydrylases: $O$-acetylserine sulphydrylase-A and $O$-acetylserine sulphydrylase-B, coded by cys $K$ and $c y s M$, respectively (Hulanicka et al., 1979). To check whether the cysK gene is expressed in the cysE cysB2971 strain, the crude extract of this strain was titrated with antibodies against the wild-type $O$-acetylserine sulphydrylase-A (Fig. 1). The decrease in enzyme activity after addition of antibodies indicates that $O$-acetylserine sulphydrylase was present in the assayed extracts. Thus the cysK gene is expressed in the cysE396 cysB2971 mutant.

\section{DISCUSSION}

This paper describes the isolation and characterization of a new class of cys $B$ mutants of $S$. typhimurium. The newly isolated triazole-resistant mutants differ from the previously described $c y s B^{c}$ strains. The cysteine biosynthetic enzymes of these mutants are regulated normally and their activities are the same as in wild-type strains (Table 3 ). They are not resistant to selenate and they can neither support growth of wild-type strains on triazole plates, nor feed cysteine auxotrophs (data not shown). Another difference was observed in the phenotype of merodiploids (data not shown). Analysis of the merodiploids $\operatorname{cys} B^{\mathrm{c}} / \operatorname{cys} B^{+}$ showed that $c y s B^{\mathrm{c}}$ is dominant to $c y s B^{+}$(Jagura \& Hulanicka, 1978), whereas cysB2971 is recessive to $c y s B^{+}$. Introduction of the $c y s B^{+}$allele on the plasmid rendered cells sensitive to triazole. After segregation of the plasmid carrying the $c y s B^{+}$allele, the cells regained their resistance to triazole.

The newly isolated mutants are similar to that peculiar cys $B 484$ mutant in one way. The cys $B 484$ allele is unusual in that it results in a $C^{-} s^{-}$phenotype with a cys $B$ effect on all the enzymes of the reductive pathway of cysteine biosynthesis, while causing the constitutive expression of $O$-acetylserine sulphydrylase (Kredich, 1971). We found that in the cysB2971 mutant carrying the cys $E$ mutation (TK2140) only the cysK gene is expressed (Table 5). This means that the impaired cys $B 2971$ product does not require the internal inducer $O$-acetyl-L-serine to permit binding of the RNA polymerase to the promoter of the $\operatorname{cys} K$ gene, whereas the presence of $O$-acetyl-L-serine is obligatory for the binding to other cysteine regulatory regions. However, the level of $O$-acetylserine sulphydrylase in TK2140 is regulated normally, whereas in the cys $B 484$ mutant it is expressed constitutively.

It is difficult to explain the triazole resistance of the $c y s B 2971$ and $c y s B 2972$ strains since they are characterized by a normal level of $O$-acetylserine sulphydrylase and lack of derepressed cysteine biosynthetic enzymes. As previously reported, a lack of $O$-acetylserine sulphydrylase or a high level of cysteine enzymes causes resistance to 1,2,4-triazole (Kredich et al., 1975). One possible explanation is that the mutated cysB protein reacts with $O$-acetylserine sulphydrylase-A and alters the site for triazolylase, which confers cell resistance to triazole. 


\section{REFERENCES}

Cheney, R. W. \& Kredich, N. M. (1975). Finestructure genetic map of the cysB locus in Salmonella typhimurium. Journal of Bacteriology 124, 1273-1281.

Filutowicz, M. \& Hulanicka, M. D. (1978). Delayed inducibility of bacterial sulphite reductase under anaerobic conditions. Abstracts of International Congress of Genetics, Moscow, C1, p.8.

Gornall, A. G., Bardawill, C. J. \& David, M. M. (1949). Determination of serum protein by means of the biuret reaction. Journal of Biological Chemistry 177, 751-766.

Hulanicka, D. \& Keopotowski, T. (1972). Mutants of Salmonella typhimurium resistant to triazole. Acta biochimica polonica 19, 25 1-260.

Hulanicka, M. D. \& Kredich, N. M. (1976). A mutation affecting expression of the gene coding for serine transacetylase in Salmonella typhimurium. Molecular and General Genetics 148, 143-148.

Hulanicka, M. D., Kredich, N. M. \& Treiman, D. M. (1974). The structural gene for $O$-acetylserine sulfhydrylase-A in Salmonella typhimurium. Journal of Biological Chemistry 249, 867-872.

Hulanicka, M. D., Hallquist, S. G., Kredich, N. M. \& MojiCA-A, T. (1979). Regulation of $O$ acetylserine sulfhydrylase-B by L-cysteine in Salmonella typhimurium. Journal of Bacteriology 140, 141-146.

JAGURA, G. \& HulaniCKA, D. (1978). Analysis of merodiploids of the cysB region in Salmonella typhimurium. Molecular and General Genetics 165, 31-38.

Jones-Mortimer, M. C. (1968). Positive control of sulphate reduction in Escherichia coli. Isolation, characterization and mapping of cysteineless mutants of E. coli K12. Biochemical Journal 110, 589-595.

KREDICH, N. M. (1971). Regulation of L-cysteine biosynthesis in Salmonella typhimurium. I. Effects of growth on varying sulfur sources and $O$-acetyl$\mathrm{L}$-serine on gene expression. Journal of Biological Chemistry 246, 3474-3484.

Kredich, N. M., Foote, L. J. \& Hulanicka, M. D. 1975). Studies on the mechanism of inhibition of Salmonella typhimurium by 1,2,4-triazole. Journal of Biological Chemistry 250, 7324-7331.

SAKAmI, W. \& Toennies, G. (1942). The investigation of amino acid reactions by methods of non-aqueous titrimetry. Journal of Biological Chemistry 144, 203-217.

Sledziewska, E. \& Hulanicka, D. (1978). Methods of isolation of cysteine constitutive mutants of the cysteine regulon in Salmonella typhimurium. Molecular and General Genetics 165, 289-293.

Smith, H. O. \& Levine, M. (1967). A phage P22 gene controlling integration of prophage. Virology 31 , 207-216.

Spencer, H. T., Collins, J. \& Monty, K. J. (1967). Sequential regulation of cysteine biosynthesis in Salmonella typhimurium. Federation Proceedings 26, 677-679.

Tully, M. D. \& YudKin, M. D. (1975). The nature of the product of the cysB gene of Escherichia coli. Molecular and General Genetics 136, 181-183.

Vito, P. C. DE \& Dreyfuss, J. (1964). Metabolic regulation of adenosinotriphosphate sulphydrylase in yeast. Journal of Bacteriology 88, 1341-1348. 